\begin{tabular}{lrr}
\hline Volume 20 & Nomor 2, Juli 2019 & Halaman 89-107 \\
URL: https://jurnal.unej.ac.id/index.php/SEMIOTIKA/index & E-ISSN: 2599-3429 & P-ISSN: 1411-5948 \\
\hline
\end{tabular}

\title{
NOVEL SIRKUS POHON KARYA ANDREA HIRATA: KAJIAN STILISTIKA
}

\section{ANDREA HIRATA'S SIRKUS POHON: STYLISTICS ANALYSIS}

\author{
Ayu Kristiana ${ }^{1}$, Heru S.P. Saputra ${ }^{2 *}$, Sri Mariati ${ }^{3}$ \\ ${ }^{1}$ Alumni Fakultas Ilmu Budaya, Universitas Jember \\ ${ }^{2,3}$ Fakultas Ilmu Budaya, Universitas Jember \\ *Corresponding Author: heruespe@gmail.com \\ Informasi Artikel:
}

Dikirim: 5/02/2019; Direvisi: 21/03/2019; Diterima: 12/04/2019

\begin{abstract}
The goal of this study is revealing the stylistic elements found in the novel entitled Sirkus Pohon by Andrea Hirata, preceding by describing the relationship between structural elements. The research method is a qualitative method with descriptive analysis based on structural theoretical concepts and stylistics. The results of the study shows that the structural elements in the novel Sirkus Pohon have a relationship between one to other element namely title, theme, character, conflict, and setting. All these five elements form the wholeness of the story. In the field of stylistics, the aesthetics of the story can be obtained from the language potentiality namely diction, sentence style and figurative language. The figurative language created by the writer are metaphor, sentence style, and personification. The potential language used by Andrea Hirata cannot be separated from the sociocultural context and also the sleight of the writer. The writer presents an intellectual figure, whereas the contextual society is a traditional and poor. It twitters people of Malay in the inland Belitung who still innocence but full of intrigue. In this novel, the appearance of pomegranates is related to the problems of love, traditional beliefs, the revival of the traveling circus, and political issues. The author expresses the traditional beliefs contradicting to the author's logic or intellect.
\end{abstract}

Keywords: potential language, aesthetic, intellectual, traditional beliefs, stylistics

Abstrak

Penelitian ini bertujuan mengungkap unsur stilistika yang terdapat dalam novel Sirkus Pohon karya Andrea Hirata, yang diawali dengan mendeskripsikan keterkaitan atarunsur struktrual. Metode penelitian yang digunakan adalah metode kualitatif dengan analisis deskriptif atas dasar konsep teoretik struktural dan stilistika. Hasil kajian menunjukkan bahwa unsur struktural dalam novel Sirkus Pohon memiliki keterkaitan antara satu unsur dan yang lain, yang meliputi judul, tema, tokoh, konflik, dan latar. Unsur-unsur struktural tersebut membentuk totalitas keutuhan cerita. Di sisi lain, dalan kajian stilistika, diperoleh gambaran bahwa efek estetika cerita dapat dihayati melalui pemanfaatan potensi bahasa, yakni melalui gaya kata, gaya kalimat, dan bahasa figuratif. Bahasa figuratif yang dikreasi oleh pengarang mencakup bahasa kias, sarana retorika, dan citraan. Potensi kebahasaan yang dimafaatkan oleh Andrea Hirata tidak dapat dilepaskan dari konteks sosial kultural dan kemahiran diri pengarang. Bertolak dari hal ini dapat dimaknai bahwa pengarang mencerminkan citra diri seorang intelektual, sedangkan konteks kisah yang diceritakan mencerminkan kondisi sosial kultural masyarakat yang masih tradisional dan terbelakang, 
yakni kehidupan orang Melayu di Pedalaman Belitung yang lugu dan penuh intrik. Dalam cerita, kemunculan pohon delima berhubungan dengan permasalahan cinta, kepercayaan tradisional, kebangkitan sirkus keliling, dan isu politik. Pengarang mengungkapkan kepercayaan tradisional yang bertentangan dengan logika atau intelektualitas pengarang.

Kata kunci: estetika, intelektualitas, kepercayaan tradisional, stilistika, potensi bahasa

\section{PENDAHULUAN}

Karya sastra tercipta oleh susunan bahasa pengarang yang menjadi medium untuk menyampaikan gagasannya. Setiap pengarang memiliki ciri khas dan gaya masing-masing dalam memanfaatkan penggunaan bahasa di dalam karya sastra. Gaya kepengarangan terkait strategi pengarang dalam menuangkan ide-idenya dalam wujud karya sastra, dengan rasa keindahan melalui medium bahasa. Penggunaan bahasa tersebut tidak terlepas dari pengaruh lingkungan sosial budaya masyarakat yang menjadi sarana pembentuk ideologi pengarang. Kemampuan pengarang dalam memanfaatkan potensi bahasa dalam karya sastra berkaitan dengan gaya kepengarangan. Salah satu pengarang Indonesia yang memperlihatkan penggunaan bahasa yang khas yaitu Andrea Hirata. Sejak terbitnya tetralogi Laskar Pelangi, nama Andrea Hirata menjadi fenomenal dalam dunia kepengarangan di Indonesia. Gaya kepengarangan Andrea Hirata mampu memanfaatkan potensi bahasa secara maksimal, mulai dari penggunaan diksi atau frase, penggunaan kalimat, penggunaan metafora, dan lain sebagainya.

Pengolahan dan pemanfaatan potensi bahasa tidak hanya muncul pada awal-awal kepengarangan Andrea, yang dimulai dengan Laskar Pelangi, tetapi juga berlanjut ke karyakarya berikutnya, termasuk karya yang kesepuluh, yakni Sirkus Pohon (Hirata, 2017). Novel ini merupakan karya yang proses penciptaanya relatif lama, hingga mencapai dua tahun, padahal karya-karya lain selesai dalam hitungan bulan. Hal ini dikarenaka Andrea harus melakukan riset di Tahiti terkait pohon delima, kisah yang menjadi bagian penting dalam novel.

Andrea Hirata dalam novel Sirkus Pohon menggambarkan kisah orang Melayu di Pedalaman Belitung yang lugu dan penuh intrik. Dikisahkan tentang seseorang yang memiliki kemampuan lebih, tetapi baru menyadari belakangan karena kemampuan tersebut terpendam. Kisah ini membandingkan tentang manusia dengan kondisi di lingkungan sekelilingnya, di antaranya dengan pohon delima dan hewan-hewan. Pohon delima menjadi fokus utama cerita. Kemunculan pohon delima berkaitan dengan permasalahan cinta, kepercayaan tradisional, kebangkitan sirkus keliling, dan isu politik. Andrea Hirata menyajikan tragedi yang diparodikan, romantika absurd, dan kesan intelektual yang mendalam. Dengan demikian, ada daya tarik lain dibandingkan karya-karya Andrea sebelumnya.

Daya tarik tersebut terbukti dari banyaknya apresiasi publik terhadap novel Sirkus Pohon. Beberapa di antaranya dilakukan oleh Ambarini, Sucipto, Wakhyuningsih, Pujawati, Asnani, Aji, Madyananda, Nindyawati, Septika, Prihartinah, dan Basid. Ambarini, Sukirno, dan Faizah (2018) mengapresiasi Sirkus Pohon dari sisi moral. Menurutnya, nilai moral dalam dalam novel tersebut mencerminakn moral yang positif dalam relasi antara manusia dengan Tuhan, dengan sesama, dan dengan diri sendiri. Hal serupa juga dipahami oleh Sucipto (2018), dengan menekankan pada relasi yang harmonis. Di sisi lain, Wakhyuningsih, Sukirno, dan Faizah (2018) lebih tertarik pada psikologi tokoh-tokoh dalam Sirkus Pohon. 
Menurutnya, Superego Hobri mampu menentukan pilihan hidup sesuai keinginannya. Hal serupa juga dipahami oleh Pujawati (2018) dan Asnani, Siregar, Hariani, dan Pardi (2018) yang menekankan bahwa masing-masing tokoh dalam Sirkus Pohon memiliki personaliti yang beragam tetapi saling menunjang.

Sementara itu, Madyananda (2016) lebih tertarik pada sisi sosiologis. Disebutkannya bahwa refleksi sosiologis tampak menonjol dari relasi sosial yang positif pada tokohtokohnya, di antaranya Hobri dan Dinda. Hal ini seakan dibenarkan oleh Nindyawati (2018) dalam kajiannya, yang menyebutkan bahwa Sirkus Pohon memiliki nilai pendidikan secara sosiologis. Di sisi lain, Aji (2019) lebih menyoroti secara sosiologis tentang persahabatan antara Hobri dan Taripol yang menunjukkan kecocokan yang saling melengkapi, meskipun keduanya dominan sisi negatifnya. Hobri adalah pengangguran yang suka dihasut, sedangkan Taripol terkenal sebagai pencuri yang kasar di Ketumbi.

Kajian Prihartinah (2009) lebih menekankan pada dimensi pendidikannya. Kajiannya menegaskan bahwa karya-karya Andrea sarat dengan pesan-pesan edukatif, termasuk upaya memberi pandangan tentang dunia pendidikan di Indonesia dan upaya yang harus dilakukan ke depannya. Hal yang tidak jauh berbeda juga dibahas oleh Septika (2018), dengan memfokuskan pada nilai-nilai pendidikan karakter. Menurutnya, novel Sirkus Pohon dapat dijadikan sebagai media pembelajaran karakter yang efektif dalam konteks pembelajaran sastra di tingkat Sekolah Menengah Atas. Sementara itu, Basid, Maulida, dan Hasyim (2018) memaparkan tentang potret nilai-nilai budaya masyarakat Belitung dalam Sirkus Pohon, termasuk nama-nama tempat dan mata pencaharian mereka, di antaranya menjadi penambang timah.

Dari paparan tersebut tampak bahwa ketertarikan pada apresiator terhadap Sirkus Pohon beragam, mulai dari aspek sosiologis, aspek psikologis, aspek pendidikan, hingga aspek bahasa. Aspek bahasa menjadi salah satu kekuatan kepengarangan Andrea Hirata sejak awal karier kepengarangannya. Persoalan yang kemudian muncul, bagaimana pemanfaatan potensi bahasa yang tercermin dalam novel Sirkus Pohon? Dalam konteks ini, pemanfaatan potensi bahasa dibatasi pada penggunaan gaya kata, gaya kalimat, bahasa figuratif, dalam relasinya dengan konteks sosial kultural. Meskipun demikian, sebelum masuk ke persoalan tersebut, perlu juga diungkapkan keterkaitan antarunsur yang membentuk keutuhan struktural novel Sirkus Pohon. Hal ini didasari oleh pemahaman bahwa kajian struktural merupakan langkah awal untuk memahami dan mengkaji lebih lanjut unsur lain (unsur ekstrinsik).

Bertolak dari hal tersebut, maka penelitian ini menekankan pada kajian struktural dan stilistika. Kajian struktural difokuskan pada upaya mengungkap keterkaitan antarunsur yang menyusun keutuhan cerita (unsur-unsur intrinsik) dalam novel Sirkus Pohon, mulai dari judul, tema, tokoh, konflik, hingga latar. Sementara itu, kajian stilistika menekankan pada upaya mengungkap pemanfaatan potensi bahasa untuk memahami gaya kepengarnagan Andrea Hirata yang tercermin dalam Sirkus Pohon. Oleh karena itu, konsep-konsep teoretik yang digunakan sebagai kerangka kajian mencakup konsep-konsep unsur struktural dan stilistika.

Sebagaimana diketahui, secara intrinsik karya sastra tersusun atas unsur-unsur yang membentuk totalitas cerita, di antaranya judul, tema, tokoh, konflik, dan latar. Judul merupakan kepala karangan yang menjadi sarana pertama yang menghubungkan antara pengarang dan pembaca. Judul dapat menunjukkan tokoh utama, alur, objek, keadaan, atau 
pengertian lain (Jones dalam Maslikatin, 2017:11). Tema merupakan makna cerita, yang mencakup tema mayor dan minor (Nurgiyantoro, 2002:82). Sementara itu, tokoh merupakan pelaku cerita, baik tokoh utama maupun tokoh bawahan/tambahan (Nurgiyantoro, 2002:176). Konflik merupakan sesuatu yang dramatik, mengacu pada pertarungan dua kekuatan (Wellek dan Warren, 2014:285), baik konflik fisik maupun psikis (Tarigan, 2011:135). Latar merupakan konteks cerita, yang mencakup tempat, waktu, dan suasana sosial (Nurgiyantoro, 2002: 227).

Unsur lain yang juga penting dalam membangun cerita adalah bahasa. Potensi bahasa menjadi modal dasar bagi pengarang untuk mengeskpresikan gagasannya dalam bentuk karya sastra. Untuk memahami potensi bahasa diperlukan perangkat konseptual, di antaranya stilistika. Stilistika merupakan ilmu tentang gaya (Ratna, 2013:8; Supriyanto, 2014:19), termasuk pemakaian bahasa dalam karya sastra (Ratna, 2013:11). Cakupan stilistika di antaranya mempelajari gaya kata, gaya kalimat, dan penggunaan bahasa figuratif (Supriyanto, 2014:31). Bahasa figuratif merupakan penggunaan bahasa yang menyimpang untuk mendapatkan efek estetis. Bahasa figuratif mencakup bahasa kias, sarana retorika, dan citraan (Supriyanto, 2014:67). Dalam kajian ini, stilistika juga digunakan untuk memahami nilai-nilai kebahasaan yang dipakai pengarang dalam novel Sirkus Pohon.

\section{METODE}

Kajian ini menggunakan metode kualitatif untuk memahami teks sastra dengan menekankan pada dimensi struktural dan stilistika. Metode kualitatif secara keseluruhan memanfaatkan cara-cara penafsiran atas teks dengan menyajikannya dalam bentuk deskriptif (Ratna, 2015:46). Dalam konteks kajian sastra, metode kualitatif diimplementasikan dalam pendekatan yang relevan, di antaranya pendekatan objektif dan ekspresif (Abrams, 1981). Pendekatan objektif diimplementasikan dalam kajian struktural untuk memahami keterkaitan antarunsur yang membentuk totalitas cerita, sedangkan pendekatan ekspresif diimplementasikan dalam kajian stilistika untuk memahami pemanfaatan potensi bahasa dalam rangka mengekspresikan gagasan dan estetika pengarang. Dalam kajian ini, pendekatan objektif (kajian struktural) digunakan sebagai analisis awal dengan mengkaji hubungan antarunsur intrinsik, di antarahnya judul, tema, tokoh, konflik, dan latar. Pendekatan ekspresif (kajian stilistika) digunakan untuk mengungkapkan pemaknaan terhadap karya sastra, meliputi gaya kata, gaya kalimat, bahasa figuratif, konteks sosial kultural dan kebahasaan pengarang.

Objek material dalam penelitian ini berupa kisah dalam wujud buku atau novel berjudul Sirkus Pohon karya Andrea Hirata, diterbitkan tahun 2017 oleh Bentang Pustaka, Yogyakarta, sedangkan objek formal berupa konsep teoretis yang terfokus pada unsur struktural dan stilistika. Sumber data dalam penelitian ini berupa novel yang menjadi objek formal tersebut, yakni Sirkus Pohon. Satuan analisis berupa teks kebahasaan yang terkait dengan unsur struktural dan unsur stilistika, dalam hal ini teks kebahasaan yang dimaksud mencakup kata, kalimat, paragraf, atau wacana. Satuan analisis tersebut merupakan data yang dinalisis sekaligus dikutip sebagai bukti objek yang dianalisis.

Teknik pengumpulan data berupa pembacaan secara berulang dan mendalam terhadap novel Sirkus Pohon guna memahami substansi cerita, untuk menemukan satuan analisis berupa kata, kalimat, paragraf, atau wacana yang menunjukkan unsur struktural dan unsur 
stilistika. Data yang didapat dari novel, kemudian dilakukan klasifikasi atas dasar konsep unsur-unsur struktural yang meliputi judul, tema, tokoh, konflik, dan latar. Di sisi lain, juga dilakukan klasifikasi data atas dasar konsep unsur-unsur silistika, yang meliputi gaya kata, gaya kalimat, dan penggunaan bahasa figuratif.

Analisis data dilakukan dengan cara menginterpretasi atau menafsirkan satuan-satuan analisis struktural, untuk kemudian mencari relasi antara satu unsur dengan unsur lain sehingga didapatkan keutuhan hubungan antarunsur struktural tersebut. Selain itu, juga dilakukan analisis terhadap satuan-satuan kebahasaan, mulai dari gaya kata, gaya kalimat, hingga penggunaan bahasa figuratif sehingga didapatkan gambaran utuh tentang ekspresi kebahasaan atau gaya kepengarangan Andrea Hirata dalam Sirkus Pohon. Selanjutnya dilakukan interpretasi atau penafsiran atas relasi-relasi struktural dan relasi-relasi kebahasaan tersebut sehingga didapatkan makna yang tersembunyi di baliknya. Makna tersebut merepresentasikan intensi Andrea Hirata yang tersirat dalam Sirkus Pohon.

\section{HASIL DAN PEMBAHASAN}

Hasil penelitian dan pembahasan atas novel Sirkus Pohon diformulasikan dalam dua bagian, yakni analisis struktural dan analisis stilistika. Mengingat bahwa kajian struktural merupakan langkah awal, dan juga mengingat bahwa ruang dalam tulisan relatif terbatas, maka analisis struktural dilakukan secara terintegrasi antara unsur yang satu dengan yang lain, bukan dianalisis unsur per unsur secara otonom. Sementara itu, mengingat bahwa kajian stilistika menjadi bagian utama dalam tulisan ini, maka analisis stilistika dipilah dalam tiga bagian, yakni gaya kata, gaya kalimat, dan bahasa figuraatif.

\section{Analisis Struktural}

Analisis struktural atas novel Sirkus Pohon mencakup analisis terhadap judul, tema, tokoh, konflik, dan latar. Atas dasar konsep teoretis tentang judul yang telah dipaparkan, maka judul pada novel Sirkus Pohon termasuk kategori judul yang mengandung beberapa pengertian. Judul novel Sirkus Pohon merupakan gabungan kata yang memiliki makna konotatif. Sirkus Pohon menggambarkan pertunjukan atau kisah yang berhubungan dengan sebuah pohon, sehingga dapat dipahami bahwa kehadiran sebuah pohon menjadi pokok utama cerita yang berkaitan dengan unsur-unsur yang lain. Pohon merupakan simbol yang dapat dimaknai sebagai kehidupan sehingga menggambarkan kisah hidup manusia yang berliku-liku. Pemilihan pohon delima sebagai pokok utama cerita juga memiliki tujuan tersendiri. Pemilihan kata delima merupakan pelesetan dari kata dilema, sehingga mengungkapkan kehidupan manusia yang penuh dilema. Pemaknaan tersebut memiliki keselarasan dengan tema yang diangkat oleh pengarang.

Tema mayor novel Sirkus Pohon yaitu dengan usaha yang gigih akan memperoleh hasil yang maksimal. Hal tersebut menunjukkan adanya kisah hidup manusia yang berlikuliku sehingga tokoh dalam novel tersebut harus berusaha dengan gigih untuk memperoleh hasil yang diinginkan. Kisah hidup yang penuh dengan dilema paling banyak dialami oleh tokoh Sobri. Hal tersebut menunjukkan bahwa Sobri merupakan tokoh utama dalam cerita. Kehidupan tokoh utama tidak akan mengalami perubahan tanpa adanya hubungan dengan tokoh-tokoh yang lain. Sobri merupakan tokoh yang tidak mudah menyerah, namun sifat tersebut tidak akan melekat pada diri Sobri tanpa adanya kehadiran tokoh tambahan. Sobri 
memiliki watak datar karena dari awal penceritaan hingga akhir cerita watak Sobri tidak berubah.Sobri menjadi tokoh yang berwatak tidak mudah menyerah, mudah dihasut, dan setia. Sobri paling banyak berhubungan dengan tokoh yang lain. Tokoh-tokoh tambahan yang hadir dalam hidup Sobri yaitu Taripol, Dinda, Tara, Tegar, Azizah, Suruhudin, Ayah, Ibu Bos, Gastori, Dukun Daud, Baderun, Jamot, dan Abdul Rapi. Tokoh Taripol memilik watak bulat karena mengalami perubahan watak. Tokoh Dinda, Tara, dan Tegar memiliki watak datar karena dari awal penceritaan hingga akhir cerita watak tokoh-tokoh tersebut tetap sama atau tidak mengalami perubahan. Setiap tokoh yang muncul memberikan dampak perubahan pada sikap tokoh yang lain.

Konflik antara manusia dan manusia dalam novel Sirkus Pohon dialami oleh Sobri dengan Taripol, Sobri dengan polisi muda, dan calon kepala desa dengan penyiar radio. Permasalahan cinta dialami Sobri ketika berhubungan dengan tokoh Dinda. Konflik terjadi ketika Dinda hilang ingatan. Sobri mengalami konflik batin yang membuat perasaannya dilema karena gagal menikah. Sobri tidak menyerah dan terus membantu Dinda agar pulih kembali. Keadaan tersebut juga menimbulkan konflik fisik yang terjadi dengan masyarakat. Masyarakat yang tinggal di pedesaan memiliki hubungan yang baik dan harmonis antarrumah. Mereka memiliki sikap ramah yang mudah untuk berkumpul sesama tetangga, namun perkumpulan tersebut juga menciptakan adanya sikap suka bergunjing. Sobri yang selalu berbicara dengan tumbuhan dan hewan-hewan untuk menenangkan jiwanya atas masalah Dinda justru dituduh sebagai orang gila. Sobri tidak menjadi orang yang pendendam. Sobri semakin menunjukkan sikap setia terhadap Dinda hingga perempuan tersebut mendapatkan ingatannya kembali. Masalah percintaan ini berhubungan pula dengan tema minor yaitu orang-orang yang setia akan mendapatkan cinta sejati.

Kemunculan pohon delima menjadi penyebab timbulnya permasalahan lain yakni konflik dengan masyarakat. Konflik tersebut berkaitan dengan latar cerita, di antaranya latar tempat. Masyarakat Kampung Ketumbi merupakan masyarakat Melayu di pedalaman Belitung. Mereka mematuhi adat istiadat setempat dan masih memegang teguh kepercayaan mistis. Logika masyarakat Kampung Ketumbi belum berjalan baik karena mereka lebih percaya perkataan dukun yang tidak masuk akal. Dukun Daud menyatakan pohon delima memiliki kekuatan mistis yang dapat mengabulkan harapan dari orang yang memeluknya. Beramai-ramai masyarakat Ketumbi memenuhi pekarangan rumah Sobri. Mereka rela membayar untuk dapat memeluk pohon keramat tersebut. Hal ini merefleksikan latar sosial berupa kondisi sosial dan pola pikir masyarakat di pedesaan yang masih mempercayai terhadap hal-hal yang tidak rasional.

Permasahan mengenai pemilihan kepala desa yang bersangkut paut dengan pohon delima terjadi karena adanya keinginan untuk menguasai banyak hal. Kekuatan pohon delima dipercaya dapat membuat calon kepala desa memenangkan pemilihan umum, sehingga pohon tersebut menjadi ajang perebutan kekuasan. Gastori sangat ingin menjadi kepala desa sehingga ia melakukan berbagai cara untuk mendapatkan kepemilikan pohon delima. Konflik antara manusia dan manusia banyak terjadi akibat perebutan kekuasan tersebut. Alam dijadikan sebagai bahan politik. Pohon delima menjadi simbol sebuah kebodohan di bidang politik. Hal ini menyimbolkan konflik manusia dengan alam. Peran sebuah pohon delima dalam novel tersebut menjadi simbolik bahwa kehidupan manusia tidak dapat terlepas dari pengaruh alam dan lingkungan sekitar. Perebutan pohon delima menjadi sindiran yang 
menunjukkan realitas politik di Indonesia. Untuk menggapai suatu hal, seseorang rela menghancurkan banyak hal yang lain, sehingga hal tersebut menunjukkan adanya keterkaitan dengan tema minor yaitu keegoisan manusia dapat menghancurkan alam. Pengarang mengambil latar tempat di Sumatra, tepatnya pedalaman Belitung karena pengarang lahir dan tumbuh di Belitung. Pengarang selalu menggunakan Belitung sebagai latar utama cerita dalam setiap novelnya. Hal tersebut menunjukkan bahwa pengarang tidak dapat lepas dari konteks sosial budayanya.

Kisah dalam novel Sirkus Pohon berlangsung dalam waktu yang lama. Pengarang tidak menyebutkan secara pasti tahun terjadinya peristiwa. Sebuah peristiwa gerhana matahari yang melintasi Kampung Ketumbi menjadi tanda bahwa kejadian dalam novel tersebut berlangsung di tahun 2016, sebagai perwujudan latar waktu. Tahun 2016 merupakan era modern yang ada dalam cerita. Peristiwa gerhana matahari terjadi di pertengahan cerita, sedangkan jalannya cerita sudah berlangsung selama sepuluh tahun berdasarkan kisah cinta Tara dan Tegar yang dimulai dari SD hingga SMA. Peristiwa gerhana matahari menjadi titik tolak bahwa peristiwa terjadi dalam rentang waktu sepuluh tahun sebelum tahun 2016 hingga beberapa bulan sesudah tahun 2016. Latar sosial ditunjukkan adanya tradisi sirkus keliling. Pertunjukan rakyat berupa sirkus keliling juga menjadi kebanggaan masyarakat Kampung Ketumbi. Sirkus keliling bukanlah kebudayaan khas Melayu, namun sirkus keliling menjadi pertunjukan rakyat yang digemari di pedalaman Belitung, suatu wilayah yang menunjukkan latar tempat. Sirkus keliling pada masa kejayaannya yakni tahun 1970-an ramai di seluruh nusantara, kemudian kehadiran sirkus keliling mulai lenyap. Tahun 1990-an sirkus keliling masih banyak mendapatkan antusias dari masyarakat di Pulau Jawa dan Pulau Sumatra, dan pada tahun 2000-an yakni ketika diceritakan dalam novel tersebut, Sirkus Keliling Blasia sudah menjadi sirkus keliling terakhir yang ada di Nusantara.

Analisis stuktural yang dilakukan secara terintegrasi antarunsur tersebut menunjukkan bahwa unsur-unsur struktural yang mencakup judul, tema, tokoh, konflik, dan latar saling berkelindan untuk membentuk keutuhan cerita. Masing-masing unsur memiliki kontribusi dalam mewujudkan totalitas cerita. Dengan demikian, relasi antarunsur dalam novel Sirkus Pohon mampu mewujudkan keutuhan konvensi struktural cerita.

\section{Analisis Stilistika}

Stilistika mengkaji bentuk dan tanda-tanda linguistik yang digunakan pengarang sebagai media ekspresi dalam mengemukakan gagasannya melalui karya sastra. Aspek- aspek stilistika yang dianalisis pada novel Sirkus Pohon karya Andrea Hirata meliputi gaya kata, gaya kalimat, bahasa figuratif, konteks sosial kultural dan kebahasaan pengarang.

\section{Gaya Kata}

Gaya kata merupakan kemampuan mengolah kata yang digunakan pengarang dalam sebuah karya sastra. Supriyanto (2014:31) membagi gaya kata dalam tiga pembahasan yaitu pilihan kata, morfologi, dan fraseologi. Pilihan kata atau diksi dibagi menjadi tiga yaitu pemanfaatan kata berbahasa daerah, pemanfaatan kata bahasa asing, dan pemanfaatan sinonim. Dalam pemanfaatan kata berbahasa daerah, pengarang menggunakan kata berbahasa daerah Melayu dan Jawa. Bahasa Melayu digunakan untuk meyakinkan latar tempat peristiwa yang berada di salah satu desa di Pulau Sumatra yang menggunakan bahasa Melayu sebagai 
bahasa sehari-hari, sebagaimana data berikut.

"A ... a ... adakah bengkel sepeda lain dekat-dekat sini, Pak Cik?"

"Dak ade, Boi, semue bingkel la tutup, urang- urang la naik motor bebek!" (Sirkus Pohon:151).

Bahasa Melayu berdasarkan data tersebut digunakan sebagai percakapan antartokoh. Kata 'Pak Cik' digunakan sebagai kata sapaan orang Melayu. Kalimat berbahasa Melayu yang menjadi jawaban atas pertanyaan Tara yaitu 'Dak ade, Boi, semue bingkel la tutup, urang-urang la naik motor bebek!' memiliki arti 'Tidak ada, nak, semua bengkel sudah tutup, orang-orang sudah menggunakan motor bebek!'. Bahasa Melayu digunakan oleh pengarang sebagai identitas diri dan menandakan bahwa pengarang tidak dapat lepas dari konteks sosial masyarakat yang melatarbelakanginya. Untuk menunjang identitas kedaerahan semacam ini, Andrea Hirata juga banyak menggunakan nama tokoh cerita dengan nama khas Melayu. Beberapa tokoh yang memiliki nama akhiran "Din" menunjukkan identitas Melayu. Namanama tokoh cerita tersebut di antaranya Sobrinudin, Sobirinudin, Suruhudin, Soridin, Baderunudin, Sanusi Syamsuludin, Debuludin, Safarudin, Halaludin, Zainal Abidin, dan Chairudin. Nama "Din" telah menjadi kebanggaan orang Melayu

Selain bahasa Melayu, pengarang menggunakan bahasa Jawa sebagai bentuk variasi dalam mengekspresikan gagasannya. Meskipun bukan orang Jawa, penggunaan bahasa Jawa menandakan luasnya wawasan kebahasaan Andrea Hirata lantaran pergaulan sosial. Berikut contoh datanya.

Kini baru terbuka mataku, siapa Taripol sebenarnya. Gorong-gorong, itulah dia, tak lebih tak kurang. Tanpa sepengetahuanku, dia rupanya telah mewisuda dirinya sendiri dari tukang nyolong tunggal, solo, menjadi tukang nyolong terorganisasi. Mafia Geng Granat, demikian peribahasa Inspektur tempo hari. Klop, menurutku (Sirkus Pohon:40).

Kata nyolong merupakan kata Bahasa Jawa yang berarti 'mencuri'. Bahasa Jawa tersebut digunakan secara sadar oleh pengarang untuk menunjukkan watak tokoh yang dinilai rendah di masyarakat. Taripol yang merupakan tukang nyolong memiliki watak sebagaimana seorang pencuri yaitu pembohong dan suka menghasut orang lain. Bahasa Jawa terdapat dalam novel Sirkus Pohon dikarenakan pengalaman pengarang yang pernah melakukan interaksi sosial dengan masyarakat Jawa ketika menempuh pendidikan di Jakarta dan bekerja di Bogor.

Selain bahasa daerah, keluasan wawasan kebahasaan juga ditunjukkan oleh Andrea dengan memanfaatkan bahasa asing, di antaranya bahasa Inggris, Portugal, Spanyol, dan Italia. Pemanfaatan bahasa Inggris dipengaruhi oleh kebiasaan pengarang ketika menempuh pendidikan di luar negeri, sehingga membuatnya mampu menguasai bahasa Inggris dengan baik. Selain bahasa Inggris, terdapat pula bahasa Portugal, misalnya amigo, Perancis, misalnya déjà $v u$, untuk judul sebuah lagu digunakan bahasa Spanyol, yaitu Livin' La Vida Loca dan Musica Para Circo, dan bahasa Italia, yaitu Con Te Partiro. Bahasa asing dari beberapa negara di Eropa tersebut digunakan oleh pengarang lantaran pengalaman pengarang yang pernah mengelilingi beberapa negara di Eropa. Hal tersebut mencerminkan wawasan 
kebahasaan Andrea yang luas.

Pemanfaatan bahasa asing tidak hanya digunakan secara normatif, melainkan juga digunakan dengan cara main-main. Artinya, pengarang menggunakan dalam versi lain, di antaranya dengan menggunakan dalam konteks plesetan. Kemampuan pengarang dalam menguasai bahasa asing dapat menciptakan kekhasan dalam bahasa pelesetan dari kosakata bahasa Inggris menjadi kosakata yang digunakan masyarakat Melayu. sebagaimana databerikut.

"Dun, ikut orang tua ke pengadilan adalah pengalaman luar biasa. Bukan seperti ikut orang tua ke pasar malam, ke kondangan, atau ke masjid. Seharusnya kau tak lupa, Boi!"

“Ojeh! Aku ingat sekarang! Aku ikut! Aku ikut!” (Sirkus Pohon:105).

Kata ojeh sering digunakan oleh tokoh cerita. Katai tersebut tidak termasuk ke dalam bahasa Indonesia atau bahasa Melayu. Kata ojeh dapat ditafsirkan pelesetan dari kata okay atau $O k$ bahasa Inggris, yang dalam bahasa Indonesia menjadi oke. Hampir semua tokoh dalam novel mengucapkan kata oke dengan mengubahnya menjadi kata ojeh. Hal tersebut menjadi kekhasan bahasa yang digunakan pengarang. Hal yang tidak jauh berbeda juga berlaku untuk kata aikonik yang diadopsi dari bahasa Inggris iconic.

Selain bahasa daerah dan asing, ada pula pemanfaatan sinonim. Pemanfaatan sinonim dalam novel Sirkus Pohon digunakan untuk menyebutkan kata sapaan yaitu dengan menggunakan kata Boi untuk menggantikan sapaan semua tokoh laki-laki maupun perempuan dalam cerita. Kata Boi berbeda konteks dari Boy dalam bahasa Inggris, yang hanya diperuntukkan bagi penyebutan laki-laki. Ada contoh sapaan lain yang digunakan oleh tokoh Sobri dan Dinda, yakni abang dan adik, yang bukan menunjukkan hubungan kakak dan adik, melainkan hubungan kekasih.

Selain diksi, pengarang juga memanfaatkan morfologi, yakni aspek kebahasaan yang mencakup penyimpangan bentuk dasar, pemendekan kata, penggunaan bentuk ulang, dan pemanfaatan kata majemuk. Penyimpangan bentuk dasar dalam novel Sirkus Pohon, di antaranya diperoleh dari penggunaan kosakata bahasa Jawa, yaitu kata percolongan. Kata percolongan berasal dari kata colong yang mendapat konfiks per-an. Pemilihan kata percolongan menimbulkan efek estetis dan memperkuat latar pedesaan dalam cerita. Penyimpangan bentuk dasar jarang ditemukan dalam novel Sirkus Pohon, sehingga efek yang ditimbulkan tidak terlalu menonjol. Sementara itu, pemendekan kata dilakukan untuk mempermudah pengucapan. Proses pemendekan kata dibagi menjadi tiga yaitu penggalan, singkatan, dan akronim. Penggalan digunakan untuk kepraktisan pengucapan sehingga menciptakan situasi cerita tampak informal, seperti kata tak, Pol, Hob, Zah, Mot. Singkatan untuk mempermudah pengungkapan sekolah, perusahaan, instansi pemerintahan, dan nama tokoh, seperti SD, SMP, SMA, IQ, PN, CV, PNS, KTP, TP, HB. Akronim digunakan untuk kelancaran pengucapan dan mengungkapkan sesuatu yang berhubungan dengan pemerintahan, seperti golput, banpres, polri, dan polsek.

Pemanfaatan aspek kebahasaan morfologi juga tercermin dalam penggunaan bentuk ulang. Bentuk ulang dijadikan sebagai sarana untuk menampilkan suasana yang memberikan kesan melebih-lebihkan. Hal ini dimanfaatkan untuk menggugah perhatian dan emosi pembaca atas situasi yang mencemaskan. Hal tersebut tampak pada data berikut. 
Masih pagi, tetapi jalanan telah ramai. Klakson bertalu-talu, salak-menyalak, gertak-menggertak. Kliningan sepeda berdering-dering, lonceng di leher lembu yang menarik kereta berdenting-denting. Motor dahulu-mendahului, angkot salip-menyalip, becak kocar-kacir, gerobak pedagang hilir-mudik. Anak-anak sekolah berjalan dan berlari-lari, sendiri-sendiri, berdua, bertiga, berombongan (SirkusPohon:20).

Pada kutipan data tersebut terdapat 12 kata yang menunjukkan penggunaan bentuk ulang. Pengarang menggambarkan suasana pagi hari di sebuah jalanan yang ramai. Pendeskripsian pengarang mengenai keramaian tersebut menggunakan bentuk ulang yang membuat tindakan masyarakat seperti anak sekolah, pengendara, dan penumpang tampak dilebih-lebihkan. Penggunaan bentuk ulang menambah greget dan kesan kecemasan atas suasana yang sedang terjadi, sehingga berimplikasi pada impresi estetis.

Di sisi lain, juga dimanfaatkan kata majemuk. Kata majemuk dalam novel Sirkus Pohon digunakan untuk memperkuat deskripsi terhadap perwatakan tokoh dan penggambaran suasana serta memberikan efek estetis. Kata majemuk yang ditemukan di antaranya pasang badan dan lintah darat.

Selain diksi dan morfologi, gaya kata juga mencakup fraseologi, yakni gabungan dua kata atau lebih yang sifatnya tidak predikatif, sehingga gabungan tersebut dapat renggang atau rapat. Fraseologi yang dibahas dalam novel Sirkus Pohon mengenai ungkapan khas bahasa Melayu. Hal ini merefleksikan bahwa pengarang bukan hanya memiliki wawasan kebahasaan yang luas, melainkan juga aspek lokalitas dari bahasa tersebut. Berikut kutipan datanya.

Selang dan belang, Kawan, perkenankan aku mengutip pepatah lama orang Melayu.Selang hanyalah noda hitam akibat tersentuh benda yang kotor, bisa dibasuh.Namun, kejahatan bagi Taripol telah menjadi belangnya.Taruhlah kucing, apalah daya membasuh belang kucing? (Sirkus Pohon:293).

Pada kutipan data tersebut, pepatah selang dan belang mengarah kepada Taripol yang menjadi pencuri dan tidak pernah jera. Pepatah tersebut dianggap pas atau representatif untuk menggambarkan sikap dan sifat Taripol, yakni sikap dan sifat yang tidak dapat dibenahi lagi dan menonjolkan nilai-nilai kejahatan yang sudah menjadi identitas diri Taripol. Pemilihan pepatah Melayu digunakan pengarang untuk memberi gambaran suasana dan karakter tokoh dengan implikasi nilai-nilai lokalitas kebudayaan Melayu, sehingga pengungkapannya lebih representatif.

\section{Gaya Kalimat}

Gaya kalimat juga dimanfaatkan oleh pengarang untuk mendapatkan efek estetis kebahasaan. Gaya kalimat dapat berupa kalimat inversi, kalimat panjang, dan kalimat pendek (Supriyanto, 2014:31). Kalimat inversi memiliki pola susunan berupa pembalikan yakni susunan predikat mendahului subjek. Hal ini dimanfaatkan oleh pengarang untuk memunculkan variasi sekaligus mendapatkan efek berbeda dari format kalimat konvensional. Pemanfaatan pola kebahasaan semacam ini mencerminkan kelihaian pengarang dalam menggunakan potensi bahasa. Contoh kalimat inversi dapat dicermati pada data berikut. 
Terdesak situasi krisis untuk ongkos hidup sehari-hari, Tegar sepakat dengan ibunya untuk melego barang apa pun yang bisa dilego. Meminjam dua gerobak pemulung besi, Tegar dan Adun mengangkut barang-barang itu menuju gang sempit di samping Bioskop Remboelan (Sirkus Pohon:153).

Kalimat inversi menekankan pada situasi atau keadaan yang sedang dihadapi tokoh cerita. Data tersebut menunjukkan kondisi keluarga Tegar setelah perceraian kedua orang tuanya. Keadaan ekonomi yang semakin memburuk ditonjolkan oleh pengarang dan sikap Tegar dalam menghadapi permasalahan tersebut. Kalimat inversi digunakan untuk memusatkan perhatian pada sesuatu atau bagian tertentu yang diinginkan pengarang.

Sementara itu, kalimat panjang digunakan untuk melukiskan kejadian dan keadaan sejelas-jelasnya. Kalimat panjang dalam novel Sirkus Pohon dapat digunakan untuk melukiskan keadaan alam, menggambarkan situasi, dan mendeskripsikan perasaan tokoh. Berikut ini datanya.

Tindakan itu menyebabkan dia melepaskan tangan dari setang, maka dia dan sepedanya dan gaya refleksnya yang konyol tadi, semuanya ambrol ke dalam parit disertai bunyi klotang, kloteng, ngak, ngok, teng, ngik, ngik, byur! Lalu, diam, sepi, senyap ... tak nampak apa-apa dari jalan raya, kecuali satu tangan mengangkat sebuah buku gambar tinggi-tinggi (Sirkus Pohon:144).

Kalimat panjang digunakan pengarang untuk mendeskripsikan keadaan ketika Tara jatuh ke parit. Data tersebut menunjukkan penggambaran situasi cerita. Pengarang memilih menggunakan kalimat panjang untuk menambah detail keadaan Tara atas peristiwa yang menimpanya, sehingga penggambaran tersebut membuat perwatakan tokoh menjadi lebih hidup. Penggunaan tanda koma, tanda seru, dan elipsis membantu pembaca mengikuti alur cerita tanpa merasa kelelahan atau bosan.

Kalimat panjang tidak membosankan apabila diselingi dengan variasi kalimat pendek. Variasi-variasi pola kalimat mencerminkan keterampilan pengarang dalam mengolah potensi bahasa. Kalimat pendek dapat digunakan dalam dialog antartokoh dan penggambaran ekspresi tokoh, sebagaimana data berikut.

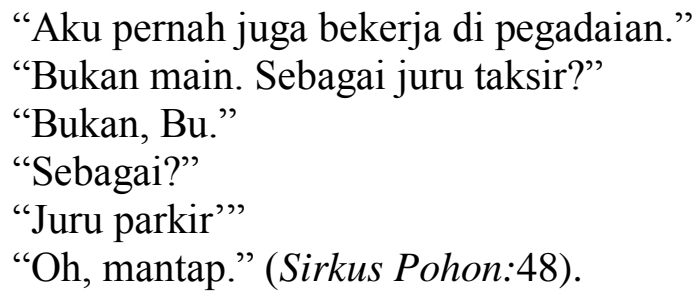

Kalimat pendek memberikan kesan kesederhanaan sehingga tidak bertele-tele dalam menyampaikan gagasannya, apalagi dalam bentuk dialog. Kalimat tersebut dibuat secara singkat dan jelas sehingga maksud yang ingin disampaikan pengarang dapat diterima dengan mudah. Tampak kesan kesederhanaan dari kalimat pendek tersebut sehingga tidak membuat pembaca kebingungan memahami alur percakapan. Kalimat pendek mampu memperlihatkan ekspresi tokoh yang lebih hidup meskipun hanya dari penggunaan satu atau dua kata dalam satu kalimat. Dengan demikian, kesan yang muncul dalam benak pembaca lebih ekspresif. 


\section{Bahasa Figuratif}

Potensi kebahasaan lain yang dimanfaatkan oleh pengarang adalah bahasa figuratif. Jika dicermati dari langsung tidaknya makna, bahasa figuratif dapat berupa bahasa kias dan sarana retorika (Keraf, 2008:129). Kedua jenis potensi kebahasaan tersebut menjadi modal penting bagi pengarang karena keterampilan dalam mengolah dan mengkreasi keduanya dapat mencerminkan kelihaian penceritaan pengarang. Kedua potensi kebahasaan tersebut juga menjadi identifikasi utama bahwa karya yang bersangkutan adalah karya sastra. Di sisi lain, potensi kebahasaan yang menjadi impresi karya sastra adalah citraan, yakni pemanfaatan potensi bahasa untuk merepresentasikan gambaran pikiran atau imaji.

Bahasa kias dalam novel Sirkus Pohon ditemukan hampir pada setiap bagian cerita, sehingga pembahasan bahasa kias mengacu pada keseluruhan isi teks. Berdasarkan analisis terhadap berbagai kategori satuan kebahasaan, bahasa kias yang dimanfaatkan oleh Andrea Hirata meliputi gaya simile, metafora, alegori, personifikasi, alusi, eponim, epitet, sinekdoke, metonimia, antonomia, ironi, sarkasme, satire, dan antifrasis. Dari keempat belas bahasa kias tersebut, yang tampak cukup menonjol adalah gaya simile, metafora, dan personifikasi. Sebagai contoh dapat ditampilkan analisis terhadap gaya simile. Gaya simile merupakan perbandingan yang bersifat eksplisit, yakni menyatakan sesuatu sama dengan hal yang lain (Keraf, 2008:138). Dalam novel, gaya simile di antaranya dimanfaatkan oleh pengarang untuk menggambarkan kampanye pemilihan kepada desa di Desa Ketumbi dengan perbandingan pola kampanye di kota besar dengan model debat calon pemimpin. Hal tersebut dapat dicermati pada data berikut.

"Di kota-kota besar sudah biasa peserta pemilihan mendebatkan rencananya sehingga rakyat tak macam membeli kucing dalam karung. Mereka berdebat di televisi. Di kampung ini ada stasiun radio AM. Meski kecil, masyarakat senang mendengar radio. Bolehlah para calon berdebat di radio (Sirkus Pohon:205).

Dalam kutipan data terdapat bagian kalimat yang menunjukkan gaya simile, yakni bagian sehingga rakyat tak macam membeli kucing dalam karung. Penggunaan gaya simile ditandai dengan pemilihan kata macam yang berarti 'seperti'. Perbandingan tersebut terjadi ketika kampanye pemilihan calon kepala desa di Desa Ketumbi disarankan untuk mengikuti cara kampanye seperti di kota-kota besar yakni dengan melakukan debat calon pemimpin. Masyarakat di kota-kota besar sudah terbiasa dengan kehadiran televisi, sehingga informasi apa pun mereka dapatkan melalui siaran televisi, sedangkan Desa Ketumbi merupakan sebuah desa di pedalaman Belitung, lebih akrab dengan radio sebagai sarana informasi mereka, sehingga debat pemilihan calon kepala desa dapat mereka laksanakan melalui siaran radio. Gaya simile digunakan untuk memberikan perbandingan yang setara. Penggunaan gaya simile sesuai dengan keadaan sosial masyarakat Kampung Ketumbi. Orang-orang yang tinggal di pedalaman kesulitan untuk berkembang sehingga mereka selalu tertinggal dalam berbagai bidang. Hal tersebut selaras dengan latar sosial masyarakat. Ungkapan tersebut menunjukkan bahwa pengarang memiliki pengetahuan lebih mengenai permasalahan politik di Indonesia. Pengarang menggunakan ungkapan yang sudah tidak asing lagi dalam dunia perpolitikan. Pengarang muncul sebagai penasihat yang memberikan arahan untuk orang-orang di pedalaman yang masih kurang ikut berperan dalam masalah politik. 
Di sisi lain, gaya ironi, satire, dan sarkasme digunakan pengarang untuk menyampaikan sindiran dan kritikan kepada publik, termasuk kepada kinerja pemerintah. Penyampaian gagasan dengan sindiran dan kritikan, baik berupa narasi maupun dialog antartokoh, merefleksikan kepedualian sosial pengarang atas situasi dan kondisi sosial di lingkungannya. Hal ini menunjukkan bahwa karya sastra mampu mengemban tugasnya, yakni dulce et utile, menyenangkan dan berguna, yang diwujudkan dalam sindiran dan kritikan sebagai wujud kepedulian. Sebagai contoh, Andrea Hirata menyindir pemerintah dengan menggunakan gaya sarkasme terkait kinerja pemerintah dalam hal mengatasi pengangguran. Berikut kutipannya.

"Karena kau tak punya keterampilan apa pun! Keterampilanmu adalah merepotkan pemerintah! Itulah keterampilanmu! Orang macam kau $n i$ jadi beban negara! Orang macam $k u$ membuka lapangan kerja untuk membantu pemerintah yang tak becus $n i$ ! Jangan salahkan tanganku yang lihai, salahkan petaruh yang tamak tu! (Sirkus Pohon:291).

Konteks kutipan data tersebut bahwa Taripol marah atas tuduhan Sobri yang menganggap dadu cangkir sebagai penipuan. Taripol menganggap permainan dadu cangkir sebagai keterampilan tangan, sehingga ia mengejek Sobri yang bodoh dan tidak memiliki keterampilan apa pun. Pengarang menyelipkan ejekan yang ditujukan kepada pemerintah dalam dialog tersebut. Ejekan tersebut terkait kinerja pemerintah yang kurang sigap dalam mengatasi persoalan pengangguran akibat minimnya lapangan pekerjaan yang disediakan. Pengangguran bukan hanya menjadi persoalan sosial di kota-kota besar, melainkan juga di desa-desa, seperti di Ketumbi. Persoalan pengangguran menjadi potret sosial atas kegagalan pemerintah, sehingga fenomena semacam itu juga melanda Ketumbi, di antaranya dialami oleh tokoh utama dalam cerita. Penggunaan gaya sarkasme menekankan pada sindiran secara langsung, terang-terangan, dan denotatif sehingga terhindar dari salah persepsi.

Selain bahasa kias, novel Sirkus Pohon juga memanfaatkan sarana retorika. Sarana retorika merupakan pemakaian bahasa yang menimbulkan efek pada pikiran pembaca. Altenbernd (dalam Pradopo, 2002:93) membedakan sarana retorika dari bahasa kiasan; keduanya berbeda. Sarana retorika merupakan suatu gaya pemakaian bahasa yang digunakan untuk muslihat pikiran sehingga menarik perhatian dan membuat pembaca merenung atau berpikir tentang sesuatu yang dikemukakan. Adapun sarana retorika yang terdapat dalam novel Sirkus Pohon yaitu aliterasi, asonasi, anastrof, asindeton, polisindeton, elipsis, litotes, tautologi, perifrasis, hiperbol, koreksio, paradoks, dan oksimoron. Sarana retorika difokuskan pada pemanfaatannya dalam memberikan efek atau pengaruh terhadap keseluruhan cerita sehingga berimplikasi pada efek estetis.

Sarana retorika yang tampak menonjol dalam novel di antaranya berupa paradoks, yakni mengungkapkan sesuatu yang berlawanan. Andrea memanfaatkan paradoks sebagai upaya untuk menciptakan sesuatu dengan efek yang lebih mengena pada benak pembaca. Penggambaran dua hal berlawanan dalam satu momentum memunculkan kesan impresif sehingga lebih melekat dalam bayangan dan ingatan pembaca. Hal tersebut dapat dicermati pada contoh data berikut.

Di tengah pasar yang ramai, kerap tiba-tiba aku disergap sepi. Kulihat sekeliling, 
ganjil, tak ada siapa-siapa. Anjing-anjing gelandang raib tak tahu ke mana. Burungburung dara yang bertengger di kawat, lenyap. Toko-toko tetap buka, tapi tak ada penjaga ataupun pembeli. Pasar Ketumbi telah berubah menjadi pasar hantu (Sirkus Pohon:256).

Data di atas memberi gambaran paradoks tentang ramai dan sepi. Gambaran semacam itu lebih mengena di benak pembaca karena terkesan lebih impresif. Data tersebut menarasikan kesepian di hati Sobri sehingga membuat dirinya berhalusinasi bahwa keadaan pasar telah berubah sunyi dan sepi sebagaimana pasar hantu yang tidak berpenghuni. Penggunaan gaya paradoks menekankan pada kondisi psikis tokoh yang terganggu akibat persoalan cinta. Andrea menggunakan gaya paradoks agar karakter tokoh lebih mudah dimengerti oleh pembaca, terutama mengenai keadaan yang membuat keadaan batin tokoh cerita semakin galau.

Selain bahasa kias dan sarana retorika, novel Sirkus Pohon juga memanfaatkan citraan. Citraan merupakan pemanfaatan potensi bahasa untuk menimbulkan suasana khusus, menarik perhatian, dan membuat gambaran dalam pikiran dan penginderaan pembaca menjadi lebih hidup. Citraan dapat berupa citraan penglihatan, citraan pendengaran, citraan perabaan, citraan pencecapan, citraan penciuman, dan citraan gerak (Pradopo, 2002:81). Citraan penglihatan dalam novel Sirkus Pohon ditandai dengan penggunaan kata melihat, memandang, menunjuk, mengenakan, mengamati, dan mengawasi. Citraan pendengaran ditandai dengan penggunaan kata terdengar, memanggil, berkaok-kaok, berteriak, bersorak, bersahut-sahutan, dan meraung-raung. Citraan perabaan ditandai dengan penggunaan kata dingin, menggigil, panas, mengusap, dan digosok. Citraan pencecapan ditandai dengan penggunaan kata pahit dan manis. Citraan penciuman ditandai dengan penggunaan kata mengendus, aroma, pengharum, mencium, wangi, bau, dan menghirup. Citraan gerak ditandai dengan penggunaan kata berputar, menggempur, bergoyang-goyang, hilir-mudik, meluncur, menusuk, jungkir balik, dan berderai-derai. Citraan mempertegas suasana cerita dan membantu penggambaran watak tokoh menjadi lebih hidup. Citraan digunakan untuk menambah kesan kepada pembaca seolah dapat turut hadir dalam kehidupan tokoh cerita.

Dari keenam macam citraan, yang tampak menonjol dalam novel adalah citraan penglihatan. Citraan penglihatan merupakan citraan yang ditimbulkan dengan memberi rangsangan kepada indera penglihatan (mata). Citraan penglihatan dalam novel Sirkus Pohon ditandai dengan penggunaan kata melihat, memandang, menunjuk, mengenakan, mengamati, mengawasi, dan sebagainya. Hal tersebut dapat dicermati pada data berikut.

Was-was aku melihat orang-orang yang kukenal celingukan di muka rumahku, kusapa, mereka lekas-lekas berlalu naik motor, lalu mereka datang lagi. Melalui celah dinding papan, kuintip mereka menunjuknunjuk pohon delima itu. Demikian berharihari. Ada pula yang memotret delima (Sirkus Pohon:78).

Berdasarkan data di atas diketahui adanya citraan penglihatan melalui penggunaan kata melihat, celingukan, kuintip, menunjuk, dan memotret. Pemilihan kata tersebut memberikan rangsangan kepada indera penglihatan. Gambaran mengenai keadaan di pekarangan rumah Sobri yang didatangi banyak orang seakan dapat dilihat oleh pembaca. Pemilihan kata-kata tersebut membuat suasana di pekarangan rumah Sobri yang ramai 
menjadi lebih nyata. Emosi Sobri yang was-was dengan keadaan yang mencekam juga tampak hidup, sehingga pembaca seolah-olah ikut melihat peristiwa tersebut.

Pembahasan tentang citraan menunjukkan bahwa pengarang memunculkan beragam jenis citraan, terutama yang mendominasi keseluruhan cerita yaitu citraan penglihatan. Citraan penglihatan dimunculkan untuk mempertegas suasana atau latar cerita. Kejelasan mengenai keadaan cerita membantu penggambaran watak tokoh sehingga menjadi lebih hidup, meskipun demikian, bukan berarti kehadiran citraan yang lain tidak memberikan efek terhadap jalannya cerita. Citraan pendengaran lebih banyak digunakan untuk menggambarkan suasana cerita yang dikombinasikan dengan penggunaan bahasa figuratif. Citraan digunakan pengarang untuk memberikan kesan kepada pembaca seolah turut hadir dalam kehidupan tokoh. Citraan penciuman juga dibutuhkan untuk menonjolkan peran Tara atau perempuan yang disebut beraroma vanili.

\section{Konteks Sosial Kultural dan Kebahasaan Pengarang}

Pemanfaatan potensi bahasa yang dilakukan oleh Andrea Hirata dalam novel Sirkus Pohon tidak terlepas dari konteks (pengaruh/implikasi) lingkungan sosial, budaya, ekonomi, dan pendidikan yang melatarbelakangi pengarang sebagai bagian dari kelompok sosial. Artinya, sebagai subjek individu, Andrea tidak dapat menafikan subjek kolektif yang ada di sekitarnya. Konteks sosial kultural, disadari atau tidak, telah menjadi bagian integral dari diri pengarang, baik menyangkut intensi maupun keterampilan kebahasaannya.

Andrea Hirata adalah penulis yang populer semenjak awal kemunculannya dengan kehadiran novel tetralogi Laskar Pelangi. Andrea mengungkapkan sisi Belitung (Belitong) yang dipenuhi oleh kemiskinan, kekuasaan PN Timah, dan rendahnya tingkat pendidikan. Banyak kritikus sastra yang menganggap kemunculan Andrea Hirata menjadi sisi positif dalam perkembangan kesusastraan Indonesia. Novel Laskar Pelangi dianggap sebagai novel yang meledak di pasaran dan meningkatkan minat baca masyarakat. Sebaliknya, tidak sedikit kritikus sastra yang menganggap kemunculan Andrea terlalu tiba-tiba, seakan masyarakat mempertanyakan: siapa sebenarnya orang ini? Telepas dari pro dan kontra mengenai kemunculan Andrea Hirata, karya-karyanya selalu menarik untuk dikaji.

Andrea Hirata dalam novel Sirkus Pohon mengungkapkan sisi Belitung yang dipenuhi oleh kemiskinan dan rendahnya tingkat pendidikan, sebagaimana pada sebagian novel sebelumnya. Pentingnya dunia pendidikan dibahas oleh Andrea sebagai wujud intelektualitasnya. Dunia pendidikan dianggap sangat penting karena dapat menjadi cara untuk membuka wawasan dan pemikiran lebih maju, serta menyelesaikan berbagai masalah kehidupan. Berbeda dari novel-novel sebelumnya, Andrea dalam novel Sirkus Pohon mencoba mengungkapkan pentingnya pendidikan melalui tokoh yang bodoh dan tidak menghargai pendidikan. Kesenangan Andrea terhadap dunia pendidikan memunculkan tokoh yang hanya berijazah SD. Pentingnya pendidikan diperlihatkan melalui fakta yang ada bahwa orang yang tidak berpendidikan akan kesulitan mendapatkan pekerjaan.

Paradoks dengan kisah tersebut, Andrea Hirata sebagai pengarang mencerminkan sosok pribadi dengan tingkat intelektualitas tinggi. Hal itu tidak terlepas dari latar belakang pendidikannya, yakni S1 di Universitas Indonesia, S2 di Universitas Sorbone dan Universitas Sheffield Hallam. Hal tersebut berimplikasi pada wawasan kebahasaannya. Andrea Hirata memanfaatkan potensi bahasa yang dikuasainya guna mengekspresikan gagasannya, yakni 
bahasa Melayu, bahasa Jawa, hingga bahasa asing (Inggris, Portugal, Spanyol, Perancis, dan Italia). Penguasaan bahasa dari ragam yang berbeda-beda tersebut tidak terlepas dari latar belakang kehidupan Andrea, yakni pernah hidup dan tinggal di lingkungan masyarakat berbahasa Melayu, Jawa, dan asing. Artinya, konteks sosiologis dari kehidupan pengarang berpengaruh pada cara pandang dan cara berbahasa Andrea.

Meskipun pengunaan bahasa Jawa dan bahasa asing dalam novel Sirkus Pohon tidak dominan, fenomena tersebut telah cukup untuk menilai keluasan wawasan kebahasaan pengarang. Selain itu, karya Andrea Hirata memiliki keunikan dalam penggunaan kosakata bahasa asing dan bahasa daerah. Andrea mengolah kosakata bahasa Jawa dan bahasa Inggris untuk menjadi bagian dari kosakata bahasa Melayu, sehingga pembaca diarahkan untuk menerima kosakata tersebut sebagai bagian dari bahasa Melayu. Simpulan ini diperkuat oleh hasil riset Kurniasari (2018) terkait pola kebahasaan Andrea Hirata dalam novel Sirkus Pohon, di antaranya tentang intejeksi. Berikut pendapat (Kurniasari, 2018:6).

Kata jeh merupakan interjeksi primer dalam bahasa Jawa Barat bagian Indramayu, dalam hal ini kata jeh sudah menyebar hingga ke daerah Belitong dan suku Melayu, kata jeh sekarang sudah menjadi bahasa yang telah disepakati di daerah Belitong bahkan sering digunakan sebagai percakapan sehari-hari.

Kajian Kurniasari tersebut menunjukkan bahwa kemampuan Andrea mengolah kata cukup baik sehingga berhasil menjadikannya sebagai kosakata "baru" dalam bahasa Melayu. Kata jeh banyak dijumpai dalam novel Sirkus Pohon terutama dalam percakapan antartokoh. Kemampuan Andrea mengolah kosakata tersebut tidak berhenti pada bagian pemanfaatan bahasa daerah, namun juga memanfaatkan penggunaan bahasa asing. Kata jeh terkadang digunakan oleh tokoh cerita dengan menambahkan satu suku kata sehingga menjadi kata ojeh. Penggunaan kata ojeh terpengaruh oleh serapan bahasa Inggris ke dalam bahasa Indonesia. Kosakata bahasa Inggris yang digunakan yaitu kata okay (atau ok), dalam serapan bahasa Indonesia pengucapannya menjadi oke.

Kemampuan mengolah kosakata bahasa asing menjadi bahasa pelesetan yang dapat diterima sebagai bahasa orang Melayu merupakan ciri khas kepengarangan Andrea Hirata. Proses tersebut menunjukkan identitas diri pengarang yang tidak dapat meninggalkan konteks sosial pengarang dalam karyanya. Andrea cukup banyak memparodikan penggunaan kosakata bahasa asing yang semakin menunjukkan kepintarannya dalam menguasai struktur kalimat bahasa Inggris.

Bukan hanya konteks kemajuan, tingginya tingkat pendidikan, atau pergaulan sosial hingga tingkat internasional yang melekat dalam benak Andrea dan kemudian diekspresikan dalam karya, melainkan juga masa lalunya, yakni masa kecil dan remaja yang banyak bergaul dengan masyarakat lokal dengan kebiasaan tradisional. Dalam Sirkus Pohon, Andrea juga banyak menggunakan peribahasa sebagai pendukung ekspresi kulturalnya. Pergaulan sosial masa lalunya dimanfaatkan sebagai bekal untuk memperkaya khazanah ekspresinya. Pergaulan sosial di tanah Belitung mampu mengasah wawasan kebahasaannya hingga terampil menciptakan peribahasa. Oleh karena itu, peribahasa cukup banyak ditemukan dalam novel Sirkus Pohon. Peribahasa itu sendiri merupakan bagian dari kekayaan sastra, terutama menjadi ciri karya sastra Melayu klasik. Penggunaan peribahasa mendukung latar cerita dalam novel Sirkus Pohon yang digunakan Andrea, yakni sebuah desa terpencil di Belitung. 
Pengarang berupaya untuk mengabadikan pengetahuan kebahasaanya melalui pola-pola kebahasaan karya sastra tradisional yang belum terpengaruh oleh modernitas. Hal tersebut dibuktikan dengan adanya peribahasa bahasa Indonesia yang kebanyakan berasal dari karya sastra Melayu klasik. Hadirnya pantun yang digunakan pengarang pada tokoh yang pernah memerankan sandiwara Melayu klasik, yaitu Dul Muluk, juga menonjolkan adanya bentuk karya sastra lama. Hal tersebut tercermin pada data berikut.

"Sulap nada untuk berlagu.

"Susun kata untuk merayu.

"Pantun lama pantun bermutu.

"Napas budaya orang Melayu."

Kutipan data berupa pantun tersebut manandakan bahwa Andrea tidak melupakan pergaulan sosial masa lalunya. Andrea ingin menunjukkan sisi tradisional dalam dirinya dengan menggunakan karya sastra lama sebagai pengetahuan kebahasaan masa lalunya. Sebagaimana diketahui, pantun merupakan bagian dari karya sastra Melayu klasik. Dengan adanya pantun, pengarang tidak melepas konteks sosial yang melatarbelakangi hadirnya novel tersebut, yakni pengalaman pergaulan sosial ketika masih remaja.

Paparan ini memberi gambaran bahwa pemanfaatan potensi bahasa yang digunakan oleh pengarang tidak dapat dilepaskan dari konteks sosial kultural dalam kehidupan dan pergaulan sosialnya. Pengarang sebagai subjek individual tidak dapat dilepaskan dari pengaruh dan implikasi subjek kolektif, yakni pergaulan sosial dan lingkungan tempat tinggalnya, baik menyangkut masa lalu maupun masa kini.

\section{SIMPULAN}

Dari analisis yang telah dilakukan dapat diketahui bahwa konvensi struktural novel Sirkus Pohon memiliki keterkaitan antarunsur, yang mencakup unsur judul, tema, tokoh, konflik, dan latar. Judul pada novel Sirkus Pohon termasuk kategori judul yang mengandung beberapa pengertian karena bermakna konotatif, dan terkait dengan unsur tema dan konflik. Tema mayor adalah usaha yang gigih akan memperoleh hasil yang maksimal. Hal itu tercermin dari perilaku tokoh utama, yakni Sobri, yang tidak dapat dilepaskan dari peran tokoh bawahan, yakni Taripol, Dinda, Tara, Tegar, Azizah, Suruhudin, Ayah, Ibu Bos, Gastori, Dukun Daud, Baderun, Jamot, dan Abdul Rapi. Hadirnya tokoh tambahan sejalan dengan munculnya konflik, baik konflik fisik maupun konflik batin. Konflik fisik, yakni antara manusia dan manusia, dialami oleh Sobri dengan Taripol, Sobri dengan polisi muda, dan calon kepala desa dengan penyiar radio. Kemunculan pohon delima menjadi penyebab timbulnya permasalahan lain yakni konflik dengan masyarakat. Sobri juga mengalami konflik batin yang membuat perasaannya dilema karena gagal menikah. Konflik tersebut berkaitan dengan latar cerita, di antaranya latar tempat, Kampung Ketumbi di pedalaman Belitung dan Tanjong Lantai. Kisah berlatar waktu tahun 2016 dan berlatar sosial kepercayaan mistis dan pertunjukan rakyat. Dengan keterjalinan antarunsur tersebut menunjukkan bahwa konvensi struktural novel Sirkus Pohon menunjukkan kesatuan dalam totalitas cerita.

Hasil analisis stilistika menunjukkan bahwa pengarang memiliki penguasaan kebahasaan yang baik dan diekspresikan dengan pola kebahasaan yang beragam sehingga menambah daya ekspresif karya, sekaligus kesan impresif pada benak pembaca. Andrea 
memanfaatkan gaya kata, gaya kalimat, bahasa figuratif, dan citraan. Gaya kata yang mencakup pilihan kata, morfologi, dan fraseologi ditunjukkan oleh pengarang secara variatif. Pengarang juga memanfaatkan potensi bahasa daerah dan bahasa asing, di samping bahasa Melayu. Bahasa derah yang digunakan adalah bahasa Jawa, sedangkan bahasa asing adalah bahasa Inggris, Portugal, Spanyol, Perancis, dan Italia. Meskipun tidak dominan, fenomena penggunaan bahasa daerah dan bahasa asing telah cukup untuk menilai keluasan wawasan kebahasaan pengarang. Pemanfaatan potensi bahasa yang digunakan oleh Andrea Hirata dalam novel Sirkus Pohon tidak terlepas dari konteks lingkungan sosial, budaya, ekonomi, dan pendidikan yang melatarbelakangi pengarang sebagai bagian dari kelompok sosial. Pengarang tidak dapat dilepaskan dari konteks sosial kultural dalam kehidupan dan pergaulan sosialnya. Pengarang sebagai subjek individual tidak dapat dilepaskan dari pengaruh dan implikasi subjek kolektif, yakni pergaulan sosial dan lingkungan tempat tinggalnya, baik menyangkut masa lalu maupun masa kini.

\section{DAFTAR PUSTAKA}

Abrams, M.H. 1981. A Glossary of Literary Terms. New York: Harcourt, Brace 7 World, Inc.

Aji, B. 2019. “Analisis Sosiologi Sastra Novel Sirkus Pohon Karya Andrea Hirata,” Skripsi. Pekan Baru: Universitas Islam Riau.

Ambarini, W.D., Sukirno, \& Faizah, U. 2018. “Analisis Nilai Moral Novel Sirkus Pohon Karya Andrea Hirata dan Rencana Pelaksanaan Pembelajarannya dengan Metode Peer Teaching di Kelas XII SMA,” Surya Bahtera, 6(52):403—409.

Asnani, Siregar, A., Hariani, S., \& Pardi. 2018. "Female Personality in Andrea Hirata's Novel Sirkus Pohon" in The 1st Annual International Conference on Language and Literature, KnE Social Sciences, pages 116-129. DOI 10.18502/kss.v3i4.1924.

Basid, A., Maulida, A., \& Hasyim, M. 2018. "Potrait of Belitung Malay Society in Novel Sirkus Pohon by Andrea Hirata Based on Subagio Sastrowardoyo Prespective." Advances in Social Science, Education and Humanities Research, volume 280. International Seminar on Recent Language, Literature, and Local Culture Studies (BASA 2018).

Hirata, A. 2017.Sirkus Pohon. Yogyakarta: Bentang Pustaka.

Keraf, G. 2008. Diksi dan Gaya Bahasa. Jakarta: Gramedia Pustaka Utama.

Kurniasari, E. 2018. "Analisis Interjeksi pada Novel Sirkus Pohon Karya Andrea Hirata". Diperoleh dari http://simki.unpkediri.ac.id/detail/14.1.01.07.0036 (diakses 16 Oktober 2018).

Madyananda, U. 2016. "Aspek Sosiologi Sastra dan Nilai Pendidikan Karakter Novel-novel Karya Andrea Hirata serta Relevansinya dengan Pembelajaran Apresiasi Prosa." Tesis. Surakarta: FKIP UNS.

Maslikatin, T. 2017. Pengantar Ilmu Sastra: Buku Ajar. Jember: Fakultas Sastra UniversitasJember.

Nindyawati, S. 2018. "Makna Persahabatan Hobri dan Taripol dalam Novel Sirkus Pohon Karya Andrea Hirata (Kajian Sosiologi Sastra)." Skripsi. Semarang: FIB Undip.

Nurgiyantoro, B. 2002. Teori Pengkajian Fiksi. Yogyakarta: Gadjah Mada University Press. 
Pradopo, R.D. 2002. Pengkajian Puisi. Yogyakarta: Gadjah Mada University Press.

Prihartinah. 2009. "Pemikiran Andrea Hirata tentang Konsep Dedikasi Pendidik dalam Tetralogi Laskar Pelangi.” Skripsi. Salatiga: STAIN Salatiga.

Pujawati, S. 2018. "Kajian Psikologi Sastra dan Nilai Pendidikan Karakter Novel Sirkus Pohon Karya Andrea Hirata serta Relevansinya sebagai Materi Pembelajaran Sastra di Sekolah Menengah Atas." Surakarta: FKIP UNS.

Ratna, N.K. 2013. Stilistika: Kajian Puitika Bahasa, Sastra, dan Budaya. Yogyakarta: Pustaka Pelajar.

Ratna, N.K. 2015.Teori, Metode, dan Teknis Penelitian Sastra. Yogyakarta: Pustaka Pelajar.

Septika, V.D. 2018. "Nilai-nilai Pendidikan Karakter dalam Novel Sirkus Pohon Karya Andrea Hirata dan Implikasinya dalam Pembelajaran Sastra di SMA.” Skripsi. Bandar Lampung: Universitas Lampung.

Sucipto, M.A.. 2018. "Nilai Moral dalam Novel Sirkus Pohon Karya Andrea Hirata: Tinjauan Sosiologi Sastra dan Implementasinya sebagai Bahan Ajar di SMK." Skripsi. Surakarta; UMS.

Supriyanto, T. 2014. Kajian Stilistika dalam Prosa. Yogyakarta: Elmatera Publishing.

Tarigan, H.G. 2011.Prinsip-prinsip Dasar Sastra. Bandung: Angkasa.

Wakhyuningsih, E., Sukirno, \& Faizah, U. 2018. "Analisis Psikologi Sastra Tokoh Utama Novel Sirkus Pohon Karya Andrea Hirata dan Rencana Pelaksanaan Pembelajarannya di SMA," Surya Bahtera, 6(52):320-326.

Wellek, R. dan Warren. A. 2014. Teori Kesusastraan. Jakarta: Gramedia Pustaka Utama. 